\title{
Production and cytomolecular identification of new wheat-perennial rye (Secale cereanum) disomic addition lines with yellow rust resistance (6R) and increased arabinoxylan and protein content $(1 \mathrm{R}, 4 \mathrm{R}, \mathrm{6R})$
}

Annamária Schneider, Marianna Rakszegi, Márta Molnár-Láng, Éva Szakács

Agricultural Institute, Centre for Agricultural Research, Hungarian Academy of Sciences, Brunszvik u. 2, H-2462 Martonvásár, Hungary

corresponding author e-mail: szakacs.eva@agrar.mta.hu

telephone: 003622569 500, fax: 003622569576

\section{Abstract}

Perennial rye (Secale cereanum, $2 \mathrm{n}=2 \mathrm{x}=14, \mathrm{RR}$ ) cultivar Kriszta has a large gene pool that can be exploited in wheat breeding. It has high protein and dietary fibre content, carries several resistance genes, tolerant to frost and drought, and adapts well to disadvantageous soil and weather conditions. In order to incorporate agronomically useful features from this perennial rye into cultivated wheat, backcross progenies derived from a cross between the wheat line Mv9kr1 and perennial rye 'Kriszta' have been produced, and addition lines disomic for $1 \mathrm{R}, 4 \mathrm{R}$ and $6 \mathrm{R}$ chromosomes have been selected using GISH, FISH and SSR markers. Quality measurements showed that addition of 'Kriszta' chromosomes 4R and 6R to the wheat genome had increased the total protein content. The 4R addition line contained slightly, while $1 \mathrm{R}$ and $6 \mathrm{R}$ additions significantly higher amount of arabinoxylan than the parental wheat line. Besides this, the $6 \mathrm{R}$ addition line appeared to be resistant to yellow rust in highly infected nurseries, consequently it may carry a new effective gene different from that harboured in the 1RS.1BL translocation for resistance to this disease.

\section{Keywords}

perennial rye (Secale cereanum), addition lines, fluorescence in situ hybridisation, SSR markers, dietary fibre, yellow rust 


\section{Acknowledgements}

This work was financed by the Hungarian National Scientific Research Fund (OTKA - No. K104382). Dietary fibre measurements were supported by OTKA 112169 project. The authors are grateful to I. Molnár for his advice regarding molecular marker analysis. The authors thank the colleagues working in the Wheat Quality Laboratory to measure the quality parameters. The technical assistance of F. Tóth, J. Bucsi and the Organic Breeding Team is gratefully acknowledged. Thanks are due to A. Bacskovszky for revising the manuscript linguistically.

\section{Conflict of interest}

The authors declare that they have no conflict of interest.

\section{Author Contribution Statement}

AS and ÉSZ selected the 1R, 4R and 6R wheat-Secale cereanum (perennial rye) addition lines from the backcross progenies of wheat-Secale cereanum, performed the FISH, GISH and molecular marker analyses and measured agronomic traits in the field and wrote the manuscript.

MR evaluated quality properties of the wheat-Secale cereanum addition lines and wrote these parts of the article.

MML started the wheat $\times$ Secale cereanum crossing programme, developed the $\mathrm{BC}_{1}$ and $\mathrm{BC}_{2}$ progenies, contributed to the manuscript writing and is the principal investigator in the OTKA K104382 project.

\section{Key message}

Wheat-Secale cereanum addition lines with yellow rust resistance (6R) and increased arabinoxylan content $(1 \mathrm{R}, 4 \mathrm{R}, 6 \mathrm{R})$ have been selected and identified in order to increase biodiversity of wheat.

\section{Ethical approval}

This article does not contain any studies with human participants or animals performed by any of the authors. 
Introduction

Cultivated and wild rye species containing $\mathrm{R}$ genomes that are non-homologous to those of wheat are important tertiary gene pools for wheat improvement. Rye (Secale cereale L. $2 n=2 x=14, R R$ ) has some significant advantages over wheat and other crops. The rye plant is more winter hardy than wheat and produces economical yields in regions where soil and weather conditions are disadvantageous for wheat production. Compared to cultivated rye, the diploid wild mountain rye (Secale montanum Guss.) that includes numerous subspecies is perennial, has a large stature, strong tillering ability, frost tolerance and resistance to diseases. However, this wild perennial rye has poor agronomic value as a forage crop because of its small and scant leaf and breaking peduncle which are problems for seed production (Akgün and Tosun, 2004). The first Secale cereale $\times S$. montanum hybrid plants (S. cereanum) in Hungary were developed in the 1950's (Kotvics 1970). The exact pedigree of the hybrids has not been published but the probable parents are S. cereale cv. Kisvárdai and S. montanum Guss. subsp. anatolicum (Boiss.) Tzvelev (on the basis of personal communication with G. Kotvics). The objective of developing these hybrids was, besides its botanical importance, to combine the best qualities of winter rye and perennial rye. The $S$. cereanum cultivar Kriszta (Kruppa 2001) has high green mass productivity, good nutritional parameters, is tolerant to frost and drought, and resistant to leaf rust, stem rust, yellow rust and powdery mildew. Owing to these attributes 'Kriszta' is an important gene source for widening genetic variability of bread wheat. 'Kriszta' has been used to develop new recombinant $1 \mathrm{~B} .1 \mathrm{R}$ translocations in order to widen the genetic diversity of this rye chromosome arm (MolnárLáng et al. 2010).

The dietary fibre (DF) content of rye is the highest among cultivated cereals. The typical rye grain contains 18 to $22 \%$ DF (Andersson et al. 2009). The major components of DF in wheat grain are the cell wall polysaccharides, arabinoxylan (AX) and (1-3)(1-4)- $\beta$-D-glucan ( $\beta$-glucan). DF can be fractionated on the basis of solubility. Soluble DF, which is more fermentable in the colon than insoluble DF, results in both lower cholesterol and glucose absorption in the small intestine and lower postprandial blood insulin levels (Moore et al. 1998; Lewis and Heaton 1999). Reduced blood cholesterol is related to reduced risk of coronary heart disease, whereas reduced blood glucose is related to reduced risk of type II diabetes. Apart from its nutritional relevance, DF is also important from a technological point of view as it strongly affects wheat functionality during cereal processing, for example, in bread-making (Courtin and Delcour, 2002). Nowadays human healthcare and a healthy 
lifestyle are in focus, and the demand for healthier food is expanding. Breeding of wheat cultivars rich in DF can satisfy this new social requirement.

Rye is an important reservoir for disease resistance genes. The short arm of rye chromosome 1R carries resistance genes against leaf rust ( $\operatorname{Lr} 26)$, stem rust $(\operatorname{Sr} 31)$, stripe rust ( $Y r 9)$ and powdery mildew (Pm8) (Friebe et al. 1996; McIntosh et al. 2003), therefore it was incorporated in tetraploid and hexaploid wheats in the form of either 1RS.1BL or 1RS.1AL chromosomal translocations (Zeller and Fuchs 1983; Friebe et al. 1989) and has been intensively used in breeding programs. The 1RS.1BL translocation, which is present in about 1050 wheat cultivars (Schlegel 2015), bears the 1R short arm of the rye cultivar Petkus. Due to the lack of allelic variation on this chromosome arm, resistance genes $\operatorname{Lr} 26, \operatorname{Pm} 8$ and $\operatorname{Yr} 9$ are no longer effective against new biotypes of diseases (Lutz et al. 1992; Bartoš 1993). More recently, virulence for $\operatorname{Sr} 31$ has been also reported (Pretorius et al. 2000, 2010). For these reasons, the importance of searching for and introducing new resistance genes into wheat cultivars has grown (Lelley et al. 2004; Molnár-Láng et al. 2010; Tang et al. 2011a).

Rye can be crossed with wheat and its agronomic traits can be transferred via classic prebreeding and breeding procedures from the hybrids into the wheat genome. In 1940 O'Mara demonstrated that the production of chromosome additions from amphidiploids backcrossed with wheat is a possible way to study the effects of individual alien chromosomes on wheat (O'Mara 1940). The first complete wheat-rye addition series created in this way was the 'Chinese Spring'-'Imperial' (Driscoll and Sears 1971) which was later chosen as the standard series of rye additions (Sybenga 1983). Currently, at least two more complete wheat-S. cereale disomic addition sets are available; the 'Chinese Spring'-'King II' (Miller 1973) and the 'Grana'-Dan'kowskie Złote (Miazga and Chrza stek 1987) addition sets. Addition lines deriving from the highly Al-tolerant Brazilian wheat line BH1146 and also tolerant rye cultivar Blanco (BH1146-Blanco and CS-Blanco sets) were produced by Lukaszewski (1988). The 'Holdfast'-'King II' series (Riley and Chapman 1958) lacks chromosome 3R, while the 'Kharkov'-'Dakold' series (Evans and Jenkins 1960) contains a 1R/3R translocation instead of chromosome 1R (Zeller 1977). Five of the additions of S. montanum to 'Chinese Spring' have also been established (Miller 1973) but it has not been possible to isolate the remaining two chromosomes (Miller 1984). Though addition lines cannot be considered as introgressions, they are stable enough to be maintained and used as starting point for the production of substitution and translocation lines.

Sophisticated molecular cytogenetic and molecular genetic methods help to analyse hybrids and their progenies in plants. Fluorescence in situ hybridization (FISH) is a powerful 
technique for detecting specific nucleic acid sequences and localizing highly repetitive DNA sequences in specific regions of individual chromosomes, thus allowing their identification (Rayburn and Gill 1985; Leitch and Heslop-Harrison 1992; Mukai et al. 1993). Rye, as an allogamous (open-pollinated) species has a genome with high heterozygosity which manifests even in polymorphic FISH signals on chromosome pairs (Szakács and Molnár-Láng 2008), but the combination of various repetitive DNA probes and analyses using rye chromosomespecific SSR (single sequence repeat) markers enable more proper identification of rye chromosomes and chromosome segments in a wheat background.

The aim of the present work was to select and identify wheat-S. cereanum addition lines from the Mv9kr1-'Kriszta' $F_{1}$ hybrid progenies using molecular cytogenetic and molecular genetic techniques to study their morphological and quality properties and to test their resistance in the field.

Materials and methods

Plant materials

\section{Production of wheat-S. cereanum addition lines}

The Martonvásári 9 krl (Mv9kr1) winter wheat line which carries the recessive crossability allele krl transferred from 'Chinese Spring' (Molnár-Láng et al. 1996) was crossed with S. cereanum cv. Kriszta in 2002. The $\mathrm{F}_{1}$ hybrids were sterile, thus young inflorescences were propagated in tissue culture (Molnár-Láng et al. 2002). The regenerated plants were backcrossed consecutively three times with the parental wheat genotype Mv9kr1 under controlled environmental conditions in 2003. The first selfing was carried out in 2005. Progeny plants were propagated and further selfed in the Martonvásár nursery. Selection of disomic addition lines from this genetic material started in 2012.

\section{Control genotypes}

In the marker analyses, the following plant materials were used as controls: wheat line Mv9kr1 and 'Mv Magdaléna' (Hungarian variety carrying 1BL.1RS translocation of 'Petkus' rye origin), wild rye Secale montanum ssp. anatolicum, rye cultivar Kriszta, and the 'Chinese Spring'-'Imperial' (CS-'Imperial') wheat-rye disomic addition series (Driscoll and Sears 1971).

\section{Comparative FISH analysis}

FISH patterns of chromosomes in the disomic additions were compared with those of $S$. montanum and rye cultivars Kriszta and Kisvárdai alacsony. 
Fluorescence in situ hybridisation (FISH) and genomic in situ hybridisation (GISH)

The seeds of the Mv9kr1×'Kriszta' hybrid derivatives were germinated at room temperature for $24 \mathrm{~h}$, incubated at $4^{\circ} \mathrm{C}$ for $48 \mathrm{~h}$ and then at $25^{\circ} \mathrm{C}$ for $26 \mathrm{~h}$. Root tips were collected and treated in ice-cold sterile water for $24 \mathrm{~h}$ and fixed in a 3:1 (v/v) mixture of $100 \%$ ethanol and acetic acid. Root-tip squash preparations were made in $45 \%$ acetic acid. The coverslips were removed in liquid nitrogen, the preparations were air dried overnight and stored at $-20^{\circ} \mathrm{C}$ until use. Total genomic DNA of Kriszta rye was labelled with digoxigenin11-dUTP using nick translation mix (Roche Diagnostics, Mannheim, Germany) and used as a probe for GISH. The FISH probe pSc119.2, a 120 bp highly repeated sequence was amplified from rye genomic DNA and labelled with biotin-11-dUTP using PCR according to Contento et al. (2005). To shorten the time-consuming screening of the large amount of wheat-perennial rye progeny plants, FISH (using pSc119.2 probe) and GISH were carried out simultaneously following the protocol described by Molnár-Láng et al. (2010), with minor modifications. The synthetic oligonucleotide (AAC) $)_{5}$ (Cuadrado et al. 2000) was amplified from rye genomic DNA using PCR according to Vrána et al. (2000) and labelled with digoxigenin-11-dUTP using nick translation mix (Roche). This DNA probe was hybridised to the slides after FISHGISH analyses of the 'Mv9kr1'-'Kriszta' disomic addition lines. Digoxigenin and biotin signals were detected with anti-digoxigenin-rhodamine (Roche, Mannheim, Germany) and streptavidin-FITC (Roche), respectively.

Images were taken using Image Pro plus 5.1 software (Media Cybernetics, Silver Spring, USA) and a Spot CCD camera (Diagnostic Instruments, Inc., Sterling Heights, USA) attached to a Zeiss Axioscope 2 epifluorescence microscope.

\section{SSR marker analysis}

Genomic DNA was extracted from fresh young leaves with QuickGene DNA tissue kit (FujiFilm, Japan) according to the manufacturer's instructions. The list of the markers used in this study is presented in Table 1. The PCR amplification was performed under the conditions described in the original publications, with minor modifications (Cseh et al. 2011; Molnár et al. 2014). Touchdown PCR was carried out in an Eppendorf Mastercycler (Eppendorf, Hamburg, Germany) using the following reaction profiles: $94^{\circ} \mathrm{C}(3 \mathrm{~min}), 6$ cycles of $\left[94^{\circ} \mathrm{C}\right.$ $\left.(20 \mathrm{sec}), 65^{\circ} \mathrm{C}(20 \mathrm{sec}), 72^{\circ} \mathrm{C}(35 \mathrm{sec})\right], 35$ cycles of $\left[94^{\circ} \mathrm{C}(15 \mathrm{sec})\right.$, primer annealing temperature $\left.(20 \mathrm{sec}), 72^{\circ} \mathrm{C}(35 \mathrm{sec})\right], 72^{\circ} \mathrm{C}(2 \mathrm{~min})$, hold at $15{ }^{\circ} \mathrm{C}$. PCR products were separated using a Fragment AnalyzerTM Automated CE System equipped with a 12-Capillary 
Array Cartridge (effective length $33 \mathrm{~cm}$ ) (Advanced Analytical Technologies, Ames, IA, USA). The results were analysed using PROsize v2.0 software.

\section{Quality measurements}

$4 \mathrm{~g}$ of seeds were milled with a ball mill (Retsch Mixer Mill MM 200) and used for compositional quality analysis.

Crude protein content was analysed by the Kjeldahl method consistent with ICC method 105/2 using the Kjeltec 1035 Analyzer. Size Exclusion - High Performance Liquid Chromatography (SE-HPLC) was used to determine the glutenin, gliadin and albumin+globulin contents and the unextractable polymeric protein (UPP\%=insoluble glutenin/soluble+insoluble glutenin) content using a modified method of Batey et al. (1991). $10 \mathrm{mg}$ flour was suspended in $1 \mathrm{ml} 0.5 \%$ (w/v) SDS in phosphate buffer (pH 6.9) and sonicated for $15 \mathrm{~s}$. After centrifugation, the supernatant was filtered on a $0.45 \mu \mathrm{m}$ PVDF filter. Analyses were performed on a Phenomenex BIOSEP-SEC 4000 column in an acetonitrile buffer $(0.05 \%(\mathrm{v} / \mathrm{v})$ triflouroacetic acid and $0.05 \%(\mathrm{v} / \mathrm{v})$ acetonitrile) with a running time of $10 \mathrm{~m}(2 \mathrm{ml} / \mathrm{m}$ flow rate). Proteins were detected by absorption at $214 \mathrm{~nm}$.

A modification of the RP-HPLC method of Marchylo et al. (1989) was used to determine the relative amounts of the HMW glutenin subunits. The gliadins were extracted with $70 \%$ $(\mathrm{v} / \mathrm{v})$ ethanol followed by $50 \%(\mathrm{v} / \mathrm{v})$ propan-1-ol. The glutenin polymers were then reduced with buffer $(50 \%$ (v/v) propan-1-ol, $2 \mathrm{M}$ urea and $0.2 \mathrm{M}$ Tris- $\mathrm{HCl}, \mathrm{pH} 6.6)$ containing $1 \%$ (w/v) DTT, and then alkylated with 4-vinylpyridine. HMW and LMW glutenin subunits were separated on a Supercosil LC-308 (300A, 3.5\% carbon, $5 \mu \mathrm{m}, 5 \times 4.6)$ column.

Total and water extractable pentosans (called arabinoxylans further on) were determined using a colorimetric method as described by Douglas (1981).

\section{Field observations}

The addition lines and the parental genotypes (Mv9kr1 and 'Kriszta') were grown in the pesticide-free (organic) Tükrös nursery in Martonvásár in two consecutive seasons (20132014 and 2014-2015) with 10 seeds in each $1 \mathrm{~m}$ row and a row spacing of $15 \mathrm{~cm}$. The same genotypes were sown in the Breeders nursery in Lászlópuszta in the 2014-2015 season in plots of $2 \mathrm{~m}^{2}$. Ten plants were randomly selected from each genotype for analysis. Plant height and tillering (spikes per plant) were measured in the field immediately before harvest, the length of the main spike, number of spikelets per main spike, number of seeds per main spike, and thousand kernel weights were recorded after harvest. 
Resistance to diseases of the Mv9kr1-'Kriszta' disomic addition lines was tested both in the pesticide-free and in the Breeders nursery.

\section{Statistical analysis}

Differences in morphological characteristics between the addition lines and the control Mv9kr1 genotype were determined by means of single factor ANOVA (analysis of variance) of the Microsoft Excel program. Values were calculated from 10 measurements and compared to the parental wheat line Mv9kr1. Because of the seeding density in the Breeders nursery, $S$. cereanum cv. Kriszta had such a high number of tillers that it was impossible to separate each plant, therefore statistical analysis was carried out only from measurements of 10 spikes.

Average arm ratio of the $1 \mathrm{R}$ chromosomes (1RL/1RS) and relative length of the $1 \mathrm{RS}$ and $1 \mathrm{RL}$ arms (1RS/1R and 1RL/1R, respectively) were calculated by means of ImageJ v1.49, a public domain Java-based image processing program. Statistical analysis of values measured in twenty cells of each $1 \mathrm{R}$ addition line was carried out using single factor ANOVA.

\section{Results}

In situ hybridisation

Identification of Mv9kr1-'Kriszta' addition lines using simultaneous FISH (with pSc119.2 probe, yellow-green colour) and GISH was carried out in the progenies of the wheat-S. cereanum hybrids to detect and identify perennial rye chromosomes in the wheat background, while the repetitive DNA probe $(\mathrm{AAC})_{5}$ (red colour) was used to identify rye chromosomes more accurately. Based on their FISH patterns, three disomic additions (1R, 4R and 6R) have been identified (Fig. 1a-f).

Mv9kr1-'Kriszta' progeny plants with identification numbers 132941, 132948 and 132949 were selected as $1 \mathrm{R}$ disomic additions. Two types of $1 \mathrm{R}$ chromosomes, each differing in pSc119.2 FISH patterns from those of S. cereale, were detected in these lines (Fig. 1a). Chromosome $1 \mathrm{R}$ of the line ' 132941 ' showed hybridisation sites terminally on the long arm, in an interstitial position on the short arm, and subterminally on the satellite (Fig. 1b). The average arm ratio, and the relative length of the 1RS and 1RL arms of this metacentric chromosome were $1.037,0.488$ and 0.512 , respectively (Table 2). Location of the pSc119.2 signals on chromosome arm 1RS of the line '132949' was similar to that observed in the line '132941', but a double interstitial signal was visible on the long arm (Fig. 1c). The average arm ratio, and the relative length of the 1RS and 1RL arms of this submetacentric chromosome were $1.443,0.409$ and 0.590 , respectively, that differed significantly from those 
found in the line '132941' (Table 2). Line '132948' carried both types of chromosome 1R (Fig. 1d, Table 2). Using the microsatellite repetitive sequence (AAC) $)_{5}$, no relevant differences were detected in FISH patterns on the 1R chromosomes of $S$. cereale, $S$. montanum, S. cereanum and the Mv9kr1-'Kriszta' 1R addition lines, except for an interstitial signal on the long arm of one member of the chromosome pair in S. cereanum.

The addition line with identification number '12641' was disomic for chromosome 4R, which could easily be identified by means of the two repetitive DNA probes. The submetacentric rye chromosome pair in this line showed a terminal pSc119.2 hybridisation site on the short arm, and an interstitial pSc119.2 and a terminal (AAC) $)_{5}$ signal on the long arm (red colour). The FISH pattern and the arm ratio of the $4 \mathrm{R}$ chromosome found in the line ' 12641 ' showed the greatest resemblance to those observed in S. cereale (Fig. 1a and e).

The rye chromosome pair of the Mv9kr1-'Kriszta' progeny line '13321' carried a double interstitial pSc119.2 signal on the long arm and a single terminal signal on the short arm. It was identified as $6 \mathrm{R}$, despite the lack of a terminal pSc119.2 hybridisation site specific for both the $S$. montanum and the 'Kriszta' 6 RL chromosome arm, and an (AAC) $)_{5}$ signal in the same position specific for S. cereale 6RL. Chromosome 6R of this addition line seemed to be more metacentric than that of the studied rye species (Fig. 1a and f).

\section{Molecular marker analysis}

Mv9kr1-'Kriszta' disomic addition lines $1 \mathrm{R}, 4 \mathrm{R}$ and $6 \mathrm{R}$ were also analysed with rye chromosome-specific PCR-based markers (Table 1) to confirm molecular cytogenetic results. PCR products of the 1RS-specific markers SCM9, TSM120, TSM81 and TSM103 were compared to the Martonvásár wheat cultivar Mv Magdaléna carrying 1RS.1BL translocation. All the four 1RS-specific markers amplified bands in the three ('132941', '132948' and '132949') 1R addition lines (Table 3), but none of them showed fragment length polymorphism compared to Mv Magdaléna (Fig. 3). 1RL-specific markers GRM0077, GRM0325 and GRM0350 produced PCR amplicons in addition lines '132948' and '132949', but no 1RL-specific bands were present in the lane containing DNA from the line '132941' (Fig. 3, Table 3). All of the 4RS- (GRM0146, GRM0324 and GRM1008) and 4RL-specific (GRM0277, MWG652, GRM1019) markers amplified PCR products both in the Chinese Spring'Imperial' and in the Mv9kr1-'Kriszta' 4R addition lines, except for GRM1019 which produced no PCR amplicons in the Chinese Spring- 'Imperial' 4R addition line (Fig. 3, Table 3). From the six 6R-specific markers (GRM0059, GRM0609, SCM304, SCM2, SCM28, and SCM180, Table 1). SCM2 specific for the long arm of the 6R chromosome produced no rye- 
specific bands in the CS-'Imperial' 6R addition, while in the Mv9kr1-'Kriszta' 6R addition line multi-banded PCR amplicons were observed (Table 3). SSR markers SCM304 and GRM0609 (specific for 6RS), and SCM28 (specific for 6RL) showed rye-specific banding patterns in both the CS-'Imperial' and the Mv9kr1-'Kriszta' 6R addition lines, while markers GRM0059 (specific for 6RS) and SCM180 (specific for 6RL) amplified the expected PCR products only in the CS-'Imperial' 6R addition line (Fig. 3, Table 3).

Morphology and yellow rust resistance of the wheat-S. cereanum addition lines

The morphological measurements from the Mv9kr1-'Kriszta' 1R, 4R and 6R disomic addition lines and the parental species were taken in both the Breeders and the pesticide-free nurseries, and data were compared to those of the parental wheat line Mv9kr1 (Tables 4 and 5). Spike morphology of these lines bore a strong resemblance to that of the parental wheat line Mv9kr1, but having awnlets towards the tip, the $1 \mathrm{R}$ addition showed the greatest similarity. Diversity of 1R addition lines '132941', '132948' and '132949' found in their pSc119.2 FISH patterns was not expressed in the spike morphology. The 4R addition line carried well-developed supernumerary spikelets. Ears of the 6R addition line were compact with a denser part at the top and were shorter than those of the $1 \mathrm{R}$ and $4 \mathrm{R}$ addition lines (Fig. $2 \mathrm{a}$ and $\mathrm{c}$ ). Plants of the $1 \mathrm{R}$ addition lines in both nurseries were significantly shorter than those of the other addition lines and the Mv9kr1 wheat line. The addition of chromosomes $1 \mathrm{R}$ and $6 \mathrm{R}$ to the Mv9kr1 genome significantly increased the tillering capacity of these introgression lines in the Breeders nursery, but no significant differences were observed in the pesticide-free nursery (Tables 4 and 5). The 4R addition line had significantly longer while the $6 \mathrm{R}$ addition line had significantly shorter spikes both in the pesticide-free and in the Breeders nursery (Tables 4 and 5). The presence of the chromosome 4R in the wheat genetic background resulted in significantly higher number of spikelets per spike in the Breeders nursery, but this effect was not recognized in the pesticide-free nursery. No significant differences in the number of seeds per main spikes were found between the wheat line Mv9kr1 and the additions in the Breeders nursery, but the added rye chromosomes in the $1 \mathrm{R}$ and $6 \mathrm{R}$ addition lines caused a significant decrease in the number of seed per spike in the pesticide-free nursery. Thousand kernel weight (TKW) data were measured in the pesticidefree nursery. It was the lowest in the $1 \mathrm{R}$, and the highest in the $6 \mathrm{R}$ addition line.

In 2014 and 2015 there were serious yellow rust epidemics in Hungary. Disease resistance of the addition lines was examined in both years and in both nurseries. Among the Mv9kr1'Kriszta' disomic addition lines only the $6 \mathrm{R}$ addition displayed yellow rust resistance from 
tillering to maturity. It had darkish green leaves without any symptoms. The infection on the plants of the $1 \mathrm{R}$ and $4 \mathrm{R}$ addition lines was just as severe as on the highly susceptible wheat parent Mv9kr1 (Fig. 2b and c).

Quality properties of the wheat-S. cereanum addition lines

Quality properties of the wheat-S.cereanum disomic addition lines were studied, especially focusing on the protein and dietary fibre components (Table 6). The total protein content of the $4 \mathrm{R}$ and $6 \mathrm{R}$ addition lines significantly increased, but the compositional properties of their proteins were very similar to the wheat control line, Mv9kr1 (Glu/Gli ratio, UPP\%). Only the quantitative ratio of the HMW glutenin subunits increased significantly in these lines, related to the LMW glutenins and there is also a small change in the Glu/Gli ratio of the $6 \mathrm{R}$ addition line. The total protein content and the Glu/Gli ratio of the Mv9kr1 did not change due to the addition of the $1 \mathrm{R}$ chromosome from Kriszta, but significant decrease were found in the UPP\% and in the ratio of the HMW and LMW glutenin subunits. It means, that the compositional properties of the glutenins changed in a way that the ratio of the large unextractable polymeric glutenins and the high molecular weight glutenins decreased, and shorter glutenin chains appeared. From qualitative point of view, it is resulting in a softer dough with smaller dough stability and poor bread-making quality.

Significant difference was found in the dietary fibre content of wheat and rye parents, especially in the total (TOTAX) and water-extractable arabinoxylan (WEAX) content. Therefore, it was expected that the addition of certain rye chromosomes would increase the fibre content of wheat. In our experiment, all the three chromosome additions significantly increased both the TOTAX and the WEAX. Addition of the S. cereanum chromosome 1R to the wheat genome almost doubled the level of the water-extractable fraction, thus exceeded the effect of chromosomes $4 \mathrm{R}$ and $6 \mathrm{R}$.

\section{Discussion}

Rye, as an open-pollinated crop, has significant genetic diversity which can be expressed in the patterns of repetitive DNA sequences within and among species (Cuadrado and Jouve 1995, 2002; Alkhimova et al. 1999), and even among cultivars (Szakács and Molnár-Láng 2008). Recent characterization of 360 repetitive elements in six species of the genus Secale implies that repetitive DNA sequences have played important roles in the course of chromosome evolution of rye (Tang et al. 2011b). 
In the present study, comparison of the $1 \mathrm{R}, 4 \mathrm{R}$ and $6 \mathrm{R}$ chromosomes of the Mv9kr1'Kriszta' addition lines with those of $S$. cereale, S. montanum and $S$. cereanum has also revealed high level of rye chromosome polymorphism (Fig. 1a). The genetic variability manifested in FISH polymorphism caused difficulties during the cytological identification of the rye chromosomes in the Mv9kr1-'Kriszta' addition lines. Using the repetitive DNA probe pSc119.2, the 1R chromosome showed polymorphic FISH signals both on the short and the long arm. Identification of $1 \mathrm{RS}$ was easy owing to its satellite, but the two strong FISH signals on the $1 \mathrm{RL}$ arm were similar to those on chromosome $6 \mathrm{R}$. Using this probe, Cuadrado and Jouve (1995) described similar double hybridisation sites on the 1RL of S. montanum. It is not probable that the Mv9kr1-'Kriszta' addition lines '132948' and '132949' carry entire $S$. montanum 1R chromosomes, because they were susceptible to diseases, but it cannot be excluded that these chromosomes are translocations between $S$. cereale (1RS) and $S$. montanum (1RL). SSR marker analysis of these lines with the 1RS-specific SCM9 confirms the $S$. cereale origin of the chromosome $1 \mathrm{R}$ short arm. The arm ratio of the metacentric and submetacentric 1R chromosomes differed significantly in the line ' 132948 '. The presence of the double interstitial pSc119.2 hybridisation sites on the long arm of the submetacentric 1R chromosome and the absence of any signal in the same position on the metacentric one, as well as the variance in the length of $1 \mathrm{RL}$ arms rather suggest that this chromosome polymorphism is the consequence of a translocation between $1 \mathrm{R}$ long arms carrying a single interstitial signal. The lack of any PCR amplifications in line '132941' using 1RL-specific markers confirms that some kind(s) of rearrangement(s) occurred in the long arm of the metacentric chromosome. Short arms of the metacentric and submetacentric chromosomes also differed in length which may be caused by an additional translocation. Presumably, lines with only one type of 1R chromosome ('132941' and '132949') derive, through chromosome segregation, from lines in which the above-mentioned translocation took place.

Regarding in situ hybridisation patterns with repetitive sequences, $4 \mathrm{R}$ is considered to be the most conservative among the rye chromosomes (Cuadrado and Jouve 1995). On the basis of the arm ratio and the distribution of FISH signals, particularly the terminal (AAC) $)_{5}$ pattern on the long arm, it was clear that the Mv9kr1-'Kriszta' disomic addition line '12641' carried a pair of chromosome 4R, and supposedly derived from $S$. cereale. The expression in this addition of the supernumerary spikelet trait confirmed the presence of the rye chromosome 4R. It seems that homologous group 4 of cereals plays an important role in the development of this spike deformity. In introgression lines bearing the chromosomes $4 \mathrm{M}^{\mathrm{g}}$ of Aegilops geniculata (Friebe et al. 1999) and 4H of Hordeum vulgare (Kruppa et al. 2013; Aranyi et al. 
2014) this morphological feature was also observed. Monosomic analyses in bread wheat revealed that, beside $2 \mathrm{D}$ and $5 \mathrm{~A}$, chromosomes $4 \mathrm{~A}$ and $4 \mathrm{~B}$ carried genes for supernumerary spikelet character (Sun et al. 2009).

Differences in FISH patterns and chromosome morphology between the 6R chromosome of the 'Mv9kr1'-'Kriszta' disomic addition line and the studied rye species suggests that significant changes occurred in this chromosome during the development of the line ' 13321 '. From the observation that the repetitive DNA sequences pSc119.2 and (AAC) ${ }_{5}$ did not show any terminal hybridisation signal on the $6 \mathrm{R}$ long arm, it can be concluded that a deletion took place in this chromosome segment. The change in the length of the 6RL chromosome arm may be the consequence of this deletion. The variability in PCR amplicon length of the 6Rspecific SSR markers suggests that the Mv9kr1-'Kriszta' 6R addition line has remarkable DNA sequence difference in primer binding sites compared to the CS-'Imperial' 6R addition line (Fig. 3 and Table 2). As the excellent yellow rust resistance of this line can exclusively originate from the $S$. montanum parental species of 'Kriszta' rye, its $6 \mathrm{R}$ is either a $S$. cereale chromosome containing chromosome segment(s) from $S$. montanum or a $S$. montanum 6R. There are evidences that chromosome $6 \mathrm{R}$ of $S$. montanum carries a pericentromeric inversion (Devos et al. 1993; Cuadrado and Jouve 1995) which can also cause the variation in the length of the PCR product. One of the possible explanations of the discrepancies found in the chromosome FISH signals is the mutagenic effect of the tissue culture used for the propagation of the wheat-S. cereanum hybrid. The chromosome-breaking nature of this in vitro technique has been described and well-studied in many plant species (Larkin and Scowcroft 1981; Phillips et al. 1994).

SSR markers are powerful tools to identify and follow alien chromosome segments in wheat introgression lines. However, sequence data are not available for $S$. montanum, one of the parental species of $S$. cereanum. Consequently, markers specific for this rye species have not been designed yet. In the present study, S. cereale-specific SSR markers were applied to verify the FISH identification of 'Kriszta' chromosome in the wheat-S. cereanum addition lines. Chromosomal location of the rye chromosome-specific SSR markers were originally assigned in CS-'Imperial' disomic addition lines (Saal and Wricke 1999), but the majority of these SSR markers produced chromosome-specific amplicons in the parental 'Kriszta' rye and the $1 \mathrm{R}, 4 \mathrm{R}$ and $6 \mathrm{R}$ wheat-S. cereanum addition lines as well (Fig. 3 and Table 2), which proves the relatively high transferability of SSR markers from $S$. cereale into $S$. cereanum.

The introgression of chromosomes $1 \mathrm{R}, 4 \mathrm{R}$ and $6 \mathrm{R}$ to the wheat line $\mathrm{Mv} 9 \mathrm{kr} 1$ resulted in changes in plant and spike morphology, but their effects on these traits were not the same in 
the organic and the Breeders nurseries. From the breeders' point of view, tillering and fertility are the two most important yield components. The number of tillers per plant determines the number of spikes per plant. It is influenced by environmental factors (water and nutrient supplies, temperature, etc.) and is under genetic control. Addition lines $1 \mathrm{R}$ and $6 \mathrm{R}$ showed significantly higher tiller number compared to Mv9kr1 in the Breeders nursery (Lászlópuszta), but no such a difference was manifested in the organic nursery (Tükrös). The two additions significantly decreased the number of seeds per main spike in Tükrös, but this effect was not noticeable in Lászlópuszta where fertility of the $1 R, 4 R$ and $6 R$ additions was practically equal to that of the parental wheat line. These data reflect well the differences in the environmental conditions of the two nurseries. The supernumerary spikelet trait of the Mv9kr1-'Kriszta' 4R addition line was also observable only in Lászlópuszta, though, because of the sterility of the extra spikelets, it did not increase the number of seeds per main spike.

Boros et al. (2002) reported that $S$. cereale chromosomes $2 \mathrm{R}, 5 \mathrm{R}$ and $6 \mathrm{R}$, in the order from the smallest to the largest effect, added to 'Chinese Spring' significantly increased arabinoxylan content in these addition lines. Based on the evaluation of DF content in disomic wheat-rye addition lines and octoploid triticale, Cyran et al. (1996) found that chromosomes $4 \mathrm{R}$ and $6 \mathrm{R}$ had an impact on the high expression of total arabinoxylan in wheat grain. The present study confirmed the positive effect of $S$. cereanum chromosome $4 \mathrm{R}$ and $6 \mathrm{R}$ on total fibre content, and also revealed their role in increasing the level of WEAX in wheat. Contrary to the above-mentioned publications, our results indicate that the expression of both the TOTAX and the WEAX are also affected by chromosome 1R. Changes in the WEAX content are really outstanding especially in the case of chromosome additions $1 \mathrm{R}$ and $6 \mathrm{R}$, but a question arises relating to this finding. Chromosome addition could also result in a decrease in the thousand kernel weight (TKW) affecting the compositional properties of the seeds in this way. However, as $1 \mathrm{R}$ chromosome resulted in a small decrease in the TKW while $6 \mathrm{R}$ chromosome resulted in a small increase in it beside similar changes in their fibre content, the effect of the TKW on the fibre content could be excluded. 'Kriszta' contains both $S$. cereale and $S$. montanum genomes, but its exact chromosome composition is unknown. S. montanum can be present as entire chromosomes or translocated chromosome segments. As the $R$ genome of the two species is very close (Riley 1955; Stutz 1957; Shewry et al. 1985), and there are no molecular markers specific for S. montanum, neither multi-colour GISH nor marker techniques are available to distinguish them. The unique behaviour of 'Kriszta' chromosome $1 \mathrm{R}$ raises the question whether this chromosome contains, as a result of 
recombination, segment(s) from $S$. montanum $1 \mathrm{R}$ carrying, by any chance, gene influencing DF content, or this gene came into $1 \mathrm{R}$ from chromosomes $4 \mathrm{R}$ or $6 \mathrm{R}$ through translocation.

Secalins are the major storage proteins of rye, which could be classified into four major groups that differ in their amino acid composition and relative molecular mass (Mr). These are the high molecular weight (HMW) secalins, $\omega$-secalins, small $\gamma$-secalins ( $\mathrm{Mr}=40000,40$ $\mathrm{kDa})$, and large $\gamma$-secalins ( $\mathrm{Mr}=75000,75 \mathrm{kDa})$ (Shewry et al. 1983a; Kasarda et al. 1983). Genes for all the HMW secalins are present on chromosome 1RL, while all the monomeric $\omega$ secalins and the small $\gamma$-secalin genes are present on chromosome 1RS both in Secale cereale and Secale montanum. In contrast, the genes for the large $\gamma$-secalins are located on $2 \mathrm{RS}$ in Secale cereale but on 6R in Secale montanum (Shewry et al. 1986). It means that rye secalins in our wheat/rye $1 \mathrm{R}$ addition lines could originate from both Secale cereale and Secale montanum, while the effect of the Secale montanum 6R chromosome could be seen on the protein composition of the $6 \mathrm{R}$ addition line. The small UPP\% and higher LMW of the $1 \mathrm{R}$ addition line refers to the presence of the HMW secalins, $\omega$-secalins and/or the small $\gamma$ secalins of rye in wheat. In the 6R addition line, the presence of the large $\gamma$-secalins might be responsible for the significant increase in the quantity of the proteins, gliadins and HMW glutenins. Despite partial homology, the rye HMW-secalin differ significantly from wheat HMW glutenin subunits with respect to their structural and quantitative parameters, which are especially important for the formation and properties of wheat gluten (De Bustos and Jouve 2003; Köhler and Wieser 2000). According to previous studies, the incorporation of the locus Glu-R1 into wheat had negative impact on the wheat processing quality (Shewry and Bechtel 2001; Lukaszewski 2006). The presence of this protein might be a reason for the poor gluten quality in our 1R addition line. Omega-secalins ( $\omega$-secalins) are regarded as the major cause of poor grain quality in rye, triticale or wheat 1BL/1RS translocation lines (Dhaliwal et al. 1990). They may have unique functions, different from those of other seed proteins (Jiang et al. 2010) and surely contribute to the quality changes in our $1 \mathrm{R}$ wheat-rye addition line. The $75 \mathrm{kDa} \gamma$-secalins are the most abundant group of secalins, accounting for greater than $50 \%$ of the total proteins in rye (Shewry et al. $1983 \mathrm{a}, \mathrm{b}$; Gellrich et al. 2003). The $75 \mathrm{kDa} \gamma$-secalin is much larger in molecular weight than the $40 \mathrm{kDa} \gamma$-secalin mainly due to the insertion of sequence in the repetitive domain (Shewry et al. 1982). This suggested that the variation in the length of the repetitive domain was related to the protein structure and the quality of rye dough. Moreover, it was predicted that the presence of the large proline/glutamine repetitive domain in the $75 \mathrm{kDa} \gamma$-secalin protein may also affect dough properties (Murray et al, 2001). In our experiment, this important type of rye protein had positive effect on wheat quality in 
the $6 \mathrm{R}$ addition line by increasing the total protein content and the ratio of HMW proteins so the chromosome addition had dough strengthening effect.

Stripe rust (yellow rust) caused by Puccinia striiformis f. sp. tritici (Pst) is a serious disease infecting in wheat producing areas with cool and moist weather conditions during the growing season. Currently, it is considered to be the most damaging rust disease all over the world including Hungary. So far, $\operatorname{Yr} 9$ gene located on the $1 \mathrm{RS}$ arm of the 1RS.1BL translocation has been the only known resistance gene against Pst in wheat, but it no longer provides protection. The Mv9kr1-'Kriszta' 6R disomic addition line is highly resistant to stripe rust as no symptoms were visible on the plants grown in the pesticide-free and the Breeders nursery in the consecutive seasons of 2013-2014 and 2014-2015, and can be considered as an excellent candidate to transfer new, effective yellow rust resistance gene(s) from rye into cultivated bread wheat. The stripe rust resistance of 'Kriszta' is obviously originates from the wild parental species $S$. montanum. It is remarkable that according to our results the resistance gene is located on chromosome 6R, while it is present on the 2RL chromosome arm of $S$. montanum ssp. africanum (Lei et al. 2013). It indicates considerable genetic diversity among the subspecies of $S$. montanum, and makes it also probable that further resistance genes are located on the individual chromosomes of Secale cereanum.

The Mv9kr1-'Kriszta' 1R, 4R and 6R disomic additions represent a large reservoir of agronomically useful genes. Among the tribe Triticeae, rye is the most tolerant species to Al toxicity (Aniol and Gustafson 1984; Gallego et al. 1998). According to previous papers, major genes influencing $\mathrm{Al}$ tolerance are located on chromosomes $3 \mathrm{R}, 4 \mathrm{R}$, and the short arm of $6 \mathrm{R}$. It appeared that $\mathrm{Al}$ tolerance was mainly due to chromosome arm 6RS and was significantly affected by the wheat background (Aniol and Gustafson 1984). Gallego and Benito (1997) found that $\mathrm{Al}$ tolerance is controlled by at least two major dominant and independent loci (Alt1 and Alt3) located on chromosomes 6RS and 4R. Powdery mildew resistance genes were also found on chromosomes 4R and 6R (Heun et al. 1990; An et al. 2013, 2015). Chromosome 6R carries a gene for resistance to cereal cyst nematode (Heterodea avenae Woll.,) as well (Asiedu et al. 1990), and a Russian wheat aphid (Diuraphis noxia Mordvilko) single dominant gene was located on chromosome 4R (Nkongolo et al. 1996).

On the basis of the results presented here and the potentials inherent in the Mv9kr1'Kriszta' 1R, 4R and 6R disomic additions, these lines can be regarded as important gene resources for wheat breading. Translocation lines deriving from these additions make possible the direct and stable transfer of valuable features such as high dietary fibre and protein 
content, as well as yellow rust resistance from $S$. cereanum to modern wheat cultivars that can be utilised in further pre-breeding and breeding projects.

\section{References}

Akgün I, Tosun M (2004) Agricultural and cytological characteristics of M1 perennial rye (Secale montanum Guss.) as effected by the application of different doses of gamma rays. Pak J Biol Sci 7:827-833. doi: 10.3923/pjbs.2004.827.833

Alkhimova AG, Heslop-Harrison JS, Shchapova AI, Vershinin AV (1999) Rye chromosome variability in wheat-rye addition and substitution lines. Chromosome Res 7:205-212. doi: 10.1023/A:1009299300018

An D, Zheng Q, Zhou Y, et al (2013) Molecular cytogenetic characterization of a new wheatrye $4 \mathrm{R}$ chromosome translocation line resistant to powdery mildew. Chromosome Res 21:419-432. doi: 10.1007/s10577-013-9366-8

An D, Zheng Q, Luo Q, et al (2015) Molecular cytogenetic identification of a new wheat-rye 6R chromosome disomic addition line with powdery mildew resistance. PLoS One. doi: 10.1371/journal.pone.0134534

Andersson R, Fransson G, Tietjen M, Åman P (2009) Content and molecular-weight distribution of dietary fibre components in whole-grain rye flour and bread. J Agric Food Chem 57:2004-2008. doi: 10.1021/jf801280f

Aniol A, Gustafson JP (1984) Chromosome location of genes controlling aluminum tolerance in wheat, rye, and triticale. Can J Genet Cytol 26:701-705. doi: 10.1139/g84-111

Aranyi NR, Molnár-Láng M, Hoffmann S, Hoffmann B (2014) Phenotypic characterization of wheat-barley "Mv9 kr1"/“Igri" introgression lines in the field. Plant Breeding 133:718-721. doi: $10.1111 /$ pbr.12213

Asiedu R, Fisher JM, Driscoll CJ (1990) Resistance to Heterodera avenue in the rye genome of triticale. Theor Appl Genet 79:331-336. doi: 10.1007/BF01186075

Bartoš P (1993) Chromosome 1R of rye in wheat breeding. Pl Breed Abst 63:1203-1211.

Batey IL, Gupta RB, MacRitchie F (1991) Use of SE-HPLC in the study of wheat flour proteins: An improved chromatographic procedure. Cereal Chem 68:207-209

Boros D, Lukaszewski AJ, Aniol A, Ochodzki P (2002) Chromosome location of genes controlling the content of dietary fibre and arabinoxylans in rye. Euphytica 128:1-8. doi: 10.1023/A:1020639601959 
Cseh A, Kruppa K, Molnár I, et al (2011) Characterization of a new 4BS.7HL wheat-barley translocation line using GISH, FISH, and SSR markers and its effect on the $\beta$-glucan content of wheat. Genome 54:795-804. doi: 10.1139/g11-044

Contento A, Heslop-Harrison JS, Schwarzacher T (2005) Diversity of a major repetitive DNA sequence in diploid and polyploid Triticeae. Cytogenetic and Genome Research 109:34-42. doi: $10.1159 / 000082379$

Courtin CM, Delcour JA (2002) Arabinoxylans and endoxylanases in wheat flour breadmaking. J Cereal Sci 35:225-243. doi: 10.1006/jcrs.2001.0433

Cuadrado A, Jouve N (1995) Fluorescent in situ hybridization and C-banding analyses of highly repetitive DNA sequences in the heterochromatin of rye (Secale montanum Guss.) and wheat incorporating S. montanum chromosome segments. Genome 38:795-802. doi: $10.1139 / \mathrm{g} 95-101$

Cuadrado A, Jouve N (2002) Evolutionary Trends of Different Repetitive DNA Sequences During Speciation in the Genus Secale. J Hered 93:339-345. doi: 10.1093/jhered/93.5.339

Cuadrado A, Schwarzacher T, Jouve N (2000) Identification of different chromatin classes in wheat using in situ hybridization with simple sequence repeat oligonucleotides. Theor Appl Genet 101:711-717. doi: 10.1007/s001220051535

Cyran M, Rakowska M, Miazga D (1996) Chromosomal location of factors affecting content and composition of non-starch polysaccharides in wheat-rye addition lines. Euphytica 89:153-157. doi: 10.1007/BF00015732

De Bustos A, Jouve N (2003) Characterisation and analysis of new HMW-glutenin alleles encoded by the Glu-R1 locus of Secale cereale. Theor Appl Genet 107:74-83. doi: $10.1007 / \mathrm{s} 00122-003-1234-\mathrm{Z}$

Devos KM, Atkinson MD, Chinoy CN, et al (1993) Chromosomal rearrangements in the rye genome relative to that of wheat. Theor Appl Genet 85:673-680. doi: 10.1007/BF00225004

Dhaliwal AS, Mares DJ, Marshall DR (1990) Measurement of dough surface stickiness associated with the 1B/1R chromosome translocation in bread wheats. J Cereal Sci 12:165175. doi: 10.1016/S0733-5210(09)80098-2

Douglas SG (1981) A rapid method for the determination of pentosans in wheat flour. Food Chemistry 7:139-145. doi: 10.1016/0308-8146(81)90059-5

Driscoll C, Sears ER (1971) Individual addition of the chromosomes of 'Imperial' rye to wheat. Agron Abst 6.

Evans LE, Jenkins BC (1960) Individual Secale Cereale Chromosome Additions to Triticum Aestivum. I. the Addition of Individual "Dakold" Fall Rye Chromosomes to "Kharkov" Winter Wheat and Their Subsequent Identification. Can J Genet Cytol 2:205-215. doi: $10.1139 / \mathrm{g} 60-021$ 
Friebe B, Heun M, Bushuk W (1989) Cytological characterization, powdery mildew resistance and storage protein composition of tetraploid and hexaploid 1BL/1RS wheat-rye translocation lines. Theor Appl Genet. doi: 10.1007/BF00265307

Friebe B, Jiang J, Raupp WJ, McIntosh RA, Gill BS (1996) Characterization of wheat-alien translocations conferring resistance to diseases and pests: current status. Euphytica 91:59-87. doi: 10.1007/BF00035277

Friebe BR, Tuleen NA, Gill BS (1999) Development and identification of a complete set of Triticum aestivum - Aegilops geniculata chromosome addition lines. Genome 42:374-380. doi: $10.1139 / \mathrm{g} 99-011$

Gallego FJ, Benito C (1997) Genetic control of aluminium tolerance in rye (Secale cereale L.). Theor Appl Genet 95:393-399. doi: 10.1007/s001220050575

Gallego FJ, Calles B, Benito C (1998) Molecular markers linked to the aluminium tolerance gene Alt1 in rye (Secale cereale L.). Theor Appl Genet 97:1104-1109. doi: $10.1007 / \mathrm{s} 001220050997$

Gellrich C, Schieberle P, Wieser H (2003) Biochemical Characterization and Quantification of the Storage Protein (Secalin) Types in Rye Flour. Cereal Chemistry Journal 80:102-109. doi: 10.1094/CCHEM.2003.80.1.102

Graner A, Jahoor A, Schondelmaier J, et al (1991) Construction of an RFLP map of barley. Theor Appl Genet 83:250-256. doi: 10.1007/BF00226259

Heun M, Friebe B, Bushuk W (1990) Chromosomal location of the powdery mildew resistance gene of Amigo wheat. Phytopathology 80:1129-1133. doi: 10.1094/Phyto-80-1129

Jiang Q-T, Wei Y-M, Andre L, et al (2010) Characterization of $\omega$-secalin genes from rye, triticale, and a wheat 1BL/1RS translocation line. J Appl Genet 51:403-411. doi: 10.1007/BF03208870

Kasarda DD, Autran J-C, Lew EJ-L, Nimmo CC, Shewry PR (1983) N-terminal amino acid sequences of $\omega$-gliadins and $\omega$-secalins. BBA-Protein Struct M 747:138-150. doi: 10.1016/0167-4838(83)90132-2

Kofler R, Bartoš J, Gong L, Stift G, Suchankova P et al (2008) Development of microsatellite markers specific for the short arm of rye (Secale cereale L.) chromosome 1. Theor Appl Genet 117:915-926. doi:10.1007/s00122-008-0831-2

Kotvics G (1970): Investigations on increasing the protein content of Secale cereale L. In: Bálint A (ed.) Protein Growth by Plant Breeding. Akadémiai Kiadó, Budapest, pp. 89-98.

Köhler P, Wieser H (2000) Comparative Studies of High MrSubunits of Rye and Wheat. III. Localisation of Cysteine Residues. J Cereal Sci 32:189-197. doi: 10.1006/jcrs.2000.0324

Kruppa J (2001) Rozs és triticale nemesítés és tájtermesztés eredményei. Dissertation. University of Debrecen (In Hungarian) 
Kruppa K, Türkösi E, Szakács É, Cseh A, Molnár-Láng M (2013) Development and identification of a 4HL.5DL wheat/barley centric fusion using GISH, FISH and SSR markers. Cereal Research Communications 41:221-229. doi: 10.1556/CRC.2012.0038

Larkin PJ, Scowcroft WR (1981) Somaclonal variation - a novel source of variability from cell cultures for plant improvement. Theor Appl Genet 60:197-214. doi: 10.1007/BF02342540

Lei M-P, Li G-R, Zhou L, et al (2013) Identification of wheat-Secale africanum chromosome $2 \mathrm{R}^{\text {afr }}$ introgression lines with novel disease resistance and agronomic characteristics. Euphytica 194:197-205. doi: 10.1007/s10681-013-0913-3

Leitch IJ, Heslop-Harrison JS (1992) Physical mapping of the 18S-5.8S-26S rRNA genes in barley by in situ hybridization. Genome 35:1013-1018. doi: 10.1139/g92-155

Lelley T, Eder C, Grausgruber H (2004) Influence of 1BL.1RS wheat-rye chromosome translocation on genotype by environment interaction. J Cereal Sci 39:313-320. doi: 10.1016/j.jcs.2003.11.003

Lewis SJ, Heaton KW (1999) The metabolic consequences of slow colonic transit. Am J Gastroenterol 94:2010-2016. doi: 10.1111/j.1572-0241.1999.01271.x

Lukaszewski AJ (1988) A comparison of several approaches in the development of disomic alien addition lines of wheat. In: Miller TE, Koebner RMD (eds), Proc. 7th Int. Wheat Genet Symp,. Cambridge, UK, pp 363-367

Lukaszewski AJ (2006) Cytogenetically engineered rye chromosomes 1R to improve breadmaking quality of hexaploid triticale. Crop Sci 46:2183-2194. doi: 10.2135/cropsci2006.03.0135

Lutz J, Limpert E, Bartoš P, Zeller FJ (1992) Identification of powdery mildew resistance genes in common wheat (Triticum aestivum L.). Plant Breeding 108:33-39. doi: 10.1111/j.1439-0523.1992.tb00097.x

Marchylo BA, Kruger JE, Hatcher DW (1989) Quantitative reversed-phase high-performance liquid chromatographic analysis of wheat storage proteins as a potential quality prediction tool. J Cereal Sci 9:113-130. doi: 10.1016/S0733-5210(89)80012-8

Martis MM, Zhou R, Haseneyer G, et al (2013) Reticulate evolution of the rye genome. Plant Cell 25:3685-3698. doi: 10.1105/tpc.113.114553

McIntosh RA, Yamazaki Y, Devos KM, et al (2003) Catalogue of gene symbols for wheat. In: Pogna NE, Romano M, Pogna EA, Galterio G (eds), Proc. 10th Intern. Wheat Genet. Symp. Vol. 4, Paestum, Italy, p 34.

Miazga D, Chrza stek M (1987) Studies on the cv. Grana wheat (Triticum aestivum L.) lines with the cv. Dan'kowskie Złote rye (Secale cereale L.) chromosome additions. I. Chromosome configurations at metaphase I. Genetica Polonica 28:327-331. 
Miller TE (1973) Alien chromosome additions and substitutions. In: Annual Report of Plant Breeding Institute. Plant Breeding Institute, Cambridge, UK, p 143

Miller TE (1984) The homoeologous relationship between the chromosomes of rye and wheat. Current status. Can J Genet Cytol 26:578-589

Molnár I, Kubaláková M, Šimková H, et al (2014) Flow cytometric chromosome sorting from diploid progenitors of bread wheat, T. urartu, Ae. speltoides and Ae. tauschii. Theor Appl Genet 127:1091-1104. doi: 10.1007/s00122-014-2282-2

Molnár-Láng M, Linc G, Sutka J (1996) Transfer of the recessive crossability allele kr1 from Chinese Spring into the winter wheat variety Martonvásári 9. Euphytica 90:301-305. doi: 10.1007/BF00027480

Molnár-Láng M, Linc G, Nagy ED, Schneider A, Molnár I (2002) Molecular cytogenetic analysis of wheat-alien hybrids and derivatives. Acta Agron Hung 50:303-311. doi: 10.1556/AAgr.50.2002.3.8

Molnár-Láng M, Cseh A, Szakács É, Molnár I (2010) Development of a wheat genotype combining the recessive crossability alleles kr1kr1kr2kr2 and the 1BL.1RS translocation, for the rapid enrichment of 1RS with new allelic variation. Theor Appl Genet 120:1535-1545. doi: $10.1007 / \mathrm{s} 00122-010-1274-0$

Moore MA, Park CB, Tsuda H (1998) Soluble and insoluble fibre influences on cancer development. Critical Reviews in Oncology/Hematology 27:229-242. doi: 10.1016/S10408428(98)00006-7

Mukai Y, Friebe B, Hatchett JH, Yamamoto M, Gill BS (1993) Molecular cytogenetic analysis of radiation-induced wheat-rye terminal and intercalary chromosomal translocations and the detection of rye chromatin specifying resistance to Hessian fly. Chromosoma 102:8895. doi: 10.1007/BF00356025

Murray FR, Skerritt JH, Appels R (2001) A gene from the Sec2 (Gli-R2) locus of a wheat 2RS.2BL chromosomal translocation line. Theor Appl Genet 102:431-439. doi: $10.1007 / \mathrm{s} 001220051664$

Nkongolo KK, Lapitan NLV, Quick JS (1996) Genetic and cytogenetic analyses of Russian wheat aphid resistance in triticale $\times$ wheat hybrids and progenies. Crop Science 36:1114. doi: 10.2135/cropsci1996.0011183X003600050007x

O'Mara JG (1940) Cytogenetic studies on triticale. I. A method for determining the effects of individual Secale chromosomes on Triticum. Genetics 25:401-408.

Phillips RL, Kaeppler SM, Olhoft P (1994) Genetic instability of plant tissue cultures: breakdown of normal controls. Proc Natl Acad Sci USA 91:5222-5226. doi: 10.1073/pnas.91.12.5222

Pretorius ZA, Bender CM, Visser B, Terefe T (2010) First report of a Puccinia graminis f. sp. tritici race virulent to the $\mathrm{Sr} 24$ and $\mathrm{Sr} 31$ wheat stem rust resistance genes in South Africa. Plant Dis 94:784-784. doi: 10.1094/PDIS-94-6-0784C 
Pretorius ZA, Singh RP, Wagoire WW, Payne TS (2000) Detection of Virulence to Wheat Stem Rust Resistance Gene Sr31 in Puccinia graminis . f. sp. tritici in Uganda. Plant Dis 84:203-203. doi: 10.1094/PDIS.2000.84.2.203B

Rayburn AL, Gill BS (1985) Use of biotin-labeled probes to map specific DNA sequences on wheat chromosomes. J Hered 76:78-81.

Riley R (1955) The cytogenetics of the differences between some Secale species. The Journal of Agricultural Science 46:377-383. doi: 10.1017/S0021859600040284

Riley R, Chapman V (1958) Riley R, Chapman V (1958) The production and phenotypes of wheat-rye chromosome addition lines. Heredity 12:301-315. doi: doi:10.1038/hdy.1958.31

Saal B, Wricke G (1999) Development of simple sequence repeat markers in rye (Secale cereale L.). Genome 42:964-972. doi: 10.1139/g99-052

Schlegel R (2015) Current list of wheats with rye and alien introgression V04-15, 1-18, http://www.rye-gene-map.de/rye-introgression

Shewry PR, Bechtel DB (2001) Morphology and chemistry of the rye grain. In: Bushuk W (ed) Rye: Production, chemistry and technology. 2nd ed., Am Assoc Cereal Chem, St. Paul, Minn., pp 69-121.

Shewry PR, Kreis M, Burgess SR, et al (1983b) The synthesis and deposition of the prolamin storage proteins (secalins) of rye. Planta 159:439-445. doi: 10.1007/BF00392080

Shewry PR, Parmar S, Miflin BJ (1983a) Extraction, separation and polymorphism of the prolamin storage proteins (secalins) of rye. Cereal Chem 60:1-6.

Shewry PR, Parmar S, Miller TE (1985) Chromosomal location of the structural genes for the Mr 75,000 $\gamma$-secalins in Secale montanum Guss: evidence for a translocation involving chromosomes $2 \mathrm{R}$ and $6 \mathrm{R}$ in cultivated rye (Secale cereale L.). Heredity 54:381-383. doi: 10.1038/hdy.1985.53

Shewry PR, Parmar S, Fulrath N, et al (1986) Chromosomal locations of the structural genes for secalins in wild perennial rye (Secale montanum Guss.) and cultivated rye (S. cereale L.) determined by two-dimensional electrophoresis. Can J Genet Cytol 28:76-83. doi: $10.1139 / g 86-010$

Shewry PR, Field JM, Lew EJ-L, Kasarda DD (1982) The purification and characterization of two groups of storage proteins (secalins) from rye (Secale cereale L.). J Exp Bot 33:261-268. doi: $10.1093 / \mathrm{jxb} / 33.2 .261$

Stutz HC (1957) A Cytogenetic Analysis of the Hybrid Secale Cereale L. x Secale Montanum Guss. and Its Progeny. Genetics 42:199-221.

Sun D, Fang J, Sun G (2009) Inheritance of genes controlling supernumerary spikelet in wheat line 51885. Euphytica 167:173-179. doi: 10.1007/s10681-008-9854-7 
Sybenga J (1983) Rye chromosome nomenclature and homoeology relationships. Workshop Report. Z Pflanzenzuecht 90: 297-304

Szakács É, Molnár-Láng M (2008) Fluorescent in situ hybridization polymorphism on the 1RS chromosome arms of cultivated Secale cereale species. Cereal Res Commun 36:247255. doi: 10.1556/CRC.36.2008.2.5

Tang Z-X, Ross K, Ren Z-L, Yang Z-J, Zhang H-Y, Chikmawati T et al (2011a) Wealth of wild species: role in plant genome elucidation and improvement. In: Kole C (ed) Wild Crop Relatives: Genomic and Breeding Resources Cereals, Springer, pp 367-395.

Tang Z-X, Fu S-L, Ren Z-L, et al (2011b) Diversity and evolution of four dispersed repetitive DNA sequences in the genus Secale. Genome 54:285-300. doi: 10.1139/g10-118

Vrána J, Kubaláková M, Simková H, et al (2000) Flow sorting of mitotic chromosomes in common wheat (Triticum aestivum L.). Genetics 156:2033-2041.

Zeller FJ (1977) Evidence for a 1R/3R translocation in the Kharkov/Dakold wheat-rye addition set. Can J Genet Cytol 19:745-748. doi: 10.1139/g77-081

Zeller FJ, Fuch E (1983) Cytologie und Krankheitsresistenz einer 1A/1R und mehrerer 1B/1R Weizen-Roggen Translokationssorten. Z Pflanzenzüchtung 90: 285-296 


\section{Figure captions}

Figure 1a: Fluorescence in situ hybridisation (FISH) patterns of the 1R, 4R and 6R chromosomes of the Hungarian rye cultivar Kisvárdai alacsony (1st row), Secale montanum (2nd row), Secale cereanum cv. Kriszta (3rd row) and the 1R, 4R and 6R chromosomes of the Mv9kr1-'Kriszta' addition lines ( $4^{\text {th }}$ row) with pSc119.2 and (AAC) $)_{5}$ repetitive DNA probes. Fig. 1b, c, d: FISH and GISH patterns on the partial cells of the three different Mv9kr1-'Kriszta' 1R disomic addition lines with diverse pSc119.2 patterns. Fig. 1e, f: Simultaneously applied GISH and FISH on the partial cells of the 4R and 6R disomic Mv9kr1-'Kriszta' addition lines. The 1R, 4R and 6R chromosomes found in the Mv9kr1-'Kriszta' disomic addition lines are enlarged in the bottom right corner.

Figure 2a, b: From left to right spikes and leaves of the wheat line Mv9kr1, 'Kriszta' perennial rye (S. cereanum), the $1 \mathrm{R}, 4 \mathrm{R}$ and $6 \mathrm{R}$ wheat-S. cereanum disomic addition lines. Fig. 2c: Spikes of the 1R, 4R and 6R Mv9kr1-'Kriszta' addition lines in the pesticide-free nursery in 2014. 'Kriszta' perennial rye and the Mv9kr1-'Kriszta' $6 \mathrm{R}$ disomic addition line showed yellow rust resistance in the pesticide-free nursery in 2014.

Figure 3: PCR amplification patterns of the SSR markers SCM9, GRM0350, GRM0324, GRM1019, GRM0609 and SCM28 on the following DNA templates (from left to right): Mv9kr1 wheat line (Mv9), 'Kriszta' perennial rye (Kr), Secale montanum (Mon), CS-'Imperial' 1R, 2R, 3R, 4R, 5R, 6R and 7R disomic addition lines (I1R-I7R), and Mv9kr1-S. cereanum cv. Kriszta 1R or $4 \mathrm{R}$ or $6 \mathrm{R}$ disomic addition lines (K1R, K4R and K6R) according to the rye chromosomespecificity of the SSR markers used. Banding patterns of the wheat-S. cereanum cv. Kriszta $1 \mathrm{R}$ disomic addition line produced with the 1RS chromosome-specific SSR marker SCM9 were compared to the Martonvásár wheat cultivar Mv Magdaléna (Mag) carrying 1RS.1BL translocation of 'Petkus' rye origin. Sample order of the wheat-'Kriszta' $1 \mathrm{R}$ addition lines (Kr1R) is '132941', '132948' and '132949'. PCR products of the markers (SCM9 and GRM0350, GRM0324 and GRM1019, GRM0609 and SCM28) specific for the rye chromosomes 1R, 4R and 6R, respectively, are marked with arrows. L: DNA ladder 


\section{Tables}

Table 1: Rye chromosome-specific SSR markers used in the present study

\begin{tabular}{|c|c|c|c|}
\hline Marker & $\begin{array}{c}\text { Annealing } \\
\text { temperature } \\
\left({ }^{\circ} \mathrm{C}\right)\end{array}$ & $\begin{array}{c}\text { Chromosome } \\
\text { location in } \\
\text { S. cereale }\end{array}$ & Reference \\
\hline SCM9 & 60 & 1RS & Saal and Wricke 1999 \\
\hline TSM81 & 60 & 1RS & Kofler et al. 2008 \\
\hline TSM103 & 60 & 1RS & Kofler et al. 2008 \\
\hline TSM120 & 60 & 1RS & Kofler et al. 2008 \\
\hline GRM0077 & 60 & 1RL & Martis et al. 2013 \\
\hline GRM0325 & 60 & 1RL & Martis et al. 2013 \\
\hline GRM0350 & 60 & 1RL & Martis et al. 2013 \\
\hline GRM0146 & 60 & 4RS & Martis et al. 2013 \\
\hline GRM0324 & 60 & 4RS & Martis et al. 2013 \\
\hline GRM1008 & 60 & 4RS & Martis et al. 2013 \\
\hline GRM0277 & 60 & 4RL & Martis et al. 2013 \\
\hline GRM1019 & 60 & 4RL & Martis et al. 2013 \\
\hline MWG652* & $55-58$ & 4RL & Graner et al. 1991 \\
\hline GRM0059 & 60 & 6RS & Martis et al. 2013 \\
\hline GRM0609 & 60 & 6RS & Martis et al. 2013 \\
\hline SCM304 & 60 & 6RS & Saal and Wricke 1999 \\
\hline SCM2 & 55 & 6RL & Saal and Wricke 1999 \\
\hline SCM28 & 60 & 6RL & Saal and Wricke 1999 \\
\hline SCM180 & 60 & 6RL & Saal and Wricke 1999 \\
\hline
\end{tabular}

*RFLP marker converted into STS-PCR marker (GrainGenes Database, http://wheat.pw.usda.gov/cgibin/GG3/report.cgi?class=marker;name=cMWG652;show=locus)

Table 2: Arm ratio of rye chromosomes 1R, and relative length of the 1RS and 1RL arms in the Mv9kr1-'Kriszta' disomic addition lines '132941', '132948' and '132949'

\begin{tabular}{|c|c|c|l|l|}
\hline \multirow{2}{*}{ Cytology number } & \multirow{2}{*}{1 morphology } & Arm ratio & \multicolumn{2}{|c|}{ Relative length } \\
& $(1 \mathrm{RL} / 1 \mathrm{RS})$ & $1 \mathrm{RS}(1 \mathrm{RS} / 1 \mathrm{R})$ & $1 \mathrm{RL}(1 \mathrm{RL} / 1 \mathrm{R})$ \\
\hline 132941 & metacentric & $1.037^{\mathrm{a}} \pm 0.018$ & $0.488^{\mathrm{c}} \pm 0.004$ & $0.512^{\mathrm{e}} \pm 0.041$ \\
\hline 132949 & submetacentric & $1.443^{\mathrm{b}} \pm 0.045^{*}$ & $0.409^{\mathrm{d}} \pm 0.007^{*}$ & $0.590^{\mathrm{f}} \pm 0.008^{*}$ \\
\hline \multirow{2}{*}{132948} & metacentric & $1.051^{\mathrm{a}} \pm 0.025$ & $0.488^{\mathrm{c}} \pm 0.004$ & $0.512^{\mathrm{e}} \pm 0.004$ \\
\cline { 2 - 5 } & submetacentric & $1.448^{\mathrm{b}} \pm 0.029^{*}$ & $0.409^{\mathrm{d}} \pm 0.009^{*}$ & $0.591^{\mathrm{f}} \pm 0.009^{*}$ \\
\hline
\end{tabular}

* Significantly different from metacentric at the $\mathrm{P}<0.01$ level

a, b: Arm ratios are not significantly different

c, d, e, f: Relative lengths are not significantly different 
Table 3: Production of PCR amplicons in wheat-Secale cereale (CS-'Imperial') and wheat-Secale cereanum (Mv9kr1-'Kriszta') 1R, 4R and 6R disomic addition lines using rye chromosome-specific SSR markers

\begin{tabular}{|l|c|c|c|c|c|c|}
\hline \multirow{2}{*}{ Marker (location) } & \multicolumn{3}{|c|}{ CS-'Imperial' } & \multicolumn{3}{c|}{ Mv9kr1-'Kriszta' } \\
& $1 \mathrm{R}$ & $4 \mathrm{R}$ & $6 \mathrm{R}$ & \multicolumn{1}{c|}{$1 \mathrm{R}$} & $4 \mathrm{R}$ & $6 \mathrm{R}$ \\
\hline SCM9 (1RS) & + & - & - & + & - & - \\
\hline TSM81 (1RS) & + & - & - & + & - & - \\
\hline TSM103 (1RS) & + & - & - & + & - & - \\
\hline TSM120 (1RS) & + & - & - & + & - & - \\
\hline GRM0077 (1RL) & + & - & - & + & - & - \\
\hline GRM0325 (1RL) & + & - & - & + & - & - \\
\hline GRM0350 (1RL) & + & - & - & + & - & - \\
\hline GRM0146 (4RS) & - & + & - & - & + & - \\
\hline GRM0324 (4RS) & - & + & - & - & + & - \\
\hline GRM1008 (4RS) & - & + & - & - & + & - \\
\hline GRM0277 (4RL) & - & + & - & - & + & - \\
\hline GRM1019 (4RL) & - & - & - & - & + & - \\
\hline MWG652 (4RL)* & - & + & - & - & + & - \\
\hline GRM0059 (6RS) & - & - & + & - & - & - \\
\hline GRM0609 (6RS) & - & - & + & - & - & + \\
\hline SCM304 (6RS) & - & - & + & - & - & + \\
\hline SCM2 (6RL) & - & - & - & - & - & + \\
\hline SCM28 (6RL) & - & - & + & - & - & + \\
\hline SCM180 (6RL) & - & - & + & - & - & - \\
\hline
\end{tabular}

+: PCR product; - : no PCR product; *RFLP marker converted into STS-PCR marker

Table 4: Morphological features of the Mv9kr1-'Kriszta' (wheat-S. cereanum) disomic 1R, 4R and 6R addition lines (Breeders nursery, 2015). Values are the means of 10 measurements and were compared to the parental wheat line Mv9kr1.

\begin{tabular}{|l|l|l|l|l|l|}
\hline \multicolumn{1}{|c|}{ Genotypes } & \multicolumn{1}{|c|}{$\begin{array}{c}\text { Plant height } \\
(\mathrm{cm})\end{array}$} & \multicolumn{1}{|c|}{$\begin{array}{c}\text { Tillering } \\
\text { (spikes/plant) }\end{array}$} & $\begin{array}{c}\text { Length of the } \\
\text { main spike } \\
(\mathrm{cm})\end{array}$ & $\begin{array}{c}\text { Spikelets/ } \\
\text { main spike }\end{array}$ & \multicolumn{1}{|c|}{$\begin{array}{c}\text { Seeds/main } \\
\text { spike }\end{array}$} \\
\hline Mv9kr1 & $68.90 \pm 2.33$ & $5.60 \pm 2.17$ & $8.31 \pm 0.48$ & $19.90 \pm 1.52$ & $50.10 \pm 4.03$ \\
\hline 'Kriszta' & $139.20 \pm 12.90$ & no data & $16.20 \pm 11.80$ & $46.60 \pm 4.97$ & $66.20 \pm 12.95$ \\
\hline addition line 1R & $62.40 \pm 4.59^{* *}$ & $8.00 \pm 2.82^{*}$ & $8.85 \pm 0.89$ & $20.40 \pm 1.26$ & $54.30 \pm 8.36$ \\
\hline addition line 4R & $70.10 \pm 2.68$ & $7.80 \pm 1.68$ & $10.65 \pm 0.50^{* *}$ & $22.30 \pm 0.94^{* *}$ & $51.10 \pm 8.14$ \\
\hline addition line 6R & $85.20 \pm 6.71^{* *}$ & $8.60 \pm 3.20^{*}$ & $7.65 \pm 0.74^{*}$ & $21.20 \pm 1.98$ & $50.10 \pm 15.17$ \\
\hline
\end{tabular}

$*$ Significantly different from Mv9kr1 at the $\mathrm{P}<0.05$ level

$* *$ Significantly different from Mv9kr1 at the $\mathrm{P}<0.01$ level 
Table5: Morphological features of the Mv9kr1-'Kriszta' (wheat-S. cereanum) disomic 1R, 4R and 6R addition lines (pesticide-free nursery, 2015). Values are the means of 10 measurements and were compared to the parental wheat line Mv9kr1.

\begin{tabular}{|l|l|l|l|l|l|l|}
\hline \multicolumn{1}{|c|}{ Genotypes } & $\begin{array}{c}\text { Plant height } \\
(\mathrm{cm})\end{array}$ & $\begin{array}{c}\text { Tillering } \\
\text { (spikes/ } \\
\text { plant })\end{array}$ & $\begin{array}{c}\text { Length of the } \\
\text { main spike } \\
(\mathrm{cm})\end{array}$ & $\begin{array}{c}\text { Spikelets/ } \\
\text { main spike }\end{array}$ & $\begin{array}{c}\text { Seeds/main } \\
\text { spike }\end{array}$ & $\begin{array}{c}\mathrm{TKW}^{1} \\
(\mathrm{~g})\end{array}$ \\
\hline Mv9kr1 & $75.30 \pm 4.57$ & $5.20 \pm 0.78$ & $9.10 \pm 0.73$ & $19.60 \pm 2.50$ & $53.80 \pm 8.43$ & 36.20 \\
\hline 'Kriszta' & $178.70 \pm 8.42$ & $11.50 \pm 4.83$ & $13.85 \pm 1.82$ & $38.80 \pm 6.28$ & $63.40 \pm 27.60$ & 19.30 \\
\hline addition line 1R & $54.85 \pm 4.56^{* *}$ & $5.50 \pm 0.84$ & $8.78 \pm 1.18$ & $18.42 \pm 1.71$ & $44.20 \pm 7.67^{*}$ & 27.10 \\
\hline addition line 4R & $75.70 \pm 2.71$ & $5.80 \pm 1.68$ & $9.95 \pm 0.83^{*}$ & $19.00 \pm 2.05$ & $46.80 \pm 10.51$ & 29.00 \\
\hline addition line 6R & $69.70 \pm 6.25$ & $5.80 \pm 1.31$ & $6.95 \pm 0.43^{* *}$ & $18.60 \pm 1.83$ & $39.90 \pm 16.05^{*}$ & 39.90 \\
\hline
\end{tabular}

1 1,000-kernel weight

* Significantly different from Mv $9 \mathrm{kr} 1$ at the $\mathrm{P}<0.05$ level

**Significantly different from Mv9kr1 at the $\mathrm{P}<0.01$ level

Table 6: Quality properties of the parental Kriszta perennial rye (S. cereanum), Mv9kr1 wheat line and Mv9kr1-'Kriszta'1R, 4R and 6R disomic addition lines grown in the pesticide-free nursery in 2014. The results are presented as the means of 2 or 3 replicates \pm standard deviation. The wheat- $S$. cereanum disomic addition lines were compared to the parental wheat genotype Mv9kr1.

\begin{tabular}{|c|c|c|c|c|c|c|}
\hline Genotypes & $\begin{array}{c}\text { total protein } \\
\%^{\mathrm{a}}\end{array}$ & Glu/Gli $^{\mathrm{b}}$ & $\mathrm{UPP}^{\mathrm{b}}$ & $\mathrm{HMW} / \mathrm{LMW}^{\mathrm{b}}$ & $\begin{array}{c}\mathrm{TOTAX}^{\mathrm{a}} \\
(\mathrm{mg} / \mathrm{g})\end{array}$ & $\begin{array}{c}\text { WEAX } \\
(\mathrm{mg} / \mathrm{g})\end{array}$ \\
\hline Kriszta & $19.00 \pm 0.08$ & $0.38 \pm 0.01$ & $26.52 \pm 2.38$ & $0.73 \pm 0.023$ & $56.45 \pm 5.70$ & $24.3 \pm 1.00$ \\
\hline Mv9kr1 & $14.90 \pm 0.05$ & $0.82 \pm 0.02$ & $43.18 \pm 2.53$ & $0.77 \pm 0.004$ & $41.39 \pm 1.73$ & $6.44 \pm 0.19$ \\
\hline $\begin{array}{c}1 \mathrm{R} \\
\text { addition line }\end{array}$ & $13.70 \pm 0.04$ & $0.88 \pm 0.05$ & $12.31 \pm 0.20^{* *}$ & $0.68 \pm 0.003^{* *}$ & $55.00 \pm 1.73^{* *}$ & $12.14 \pm 0.78^{* *}$ \\
\hline $\begin{array}{c}4 \mathrm{R} \\
\text { addition line }\end{array}$ & $17.80 \pm 0.07^{* *}$ & $0.73 \pm 0.08$ & $41.30 \pm 0.47$ & $0.89 \pm 0.006^{* *}$ & $51.52 \pm 2.45^{* *}$ & $7.84 \pm 0.12^{* *}$ \\
\hline $\begin{array}{c}6 \mathrm{R} \\
\text { addition line }\end{array}$ & $19.80 \pm 0.06^{* *}$ & $0.70 \pm 0.03^{*}$ & $41.26 \pm 2.83$ & $0.86 \pm 0.015^{* *}$ & $54.67 \pm 2.12^{* *}$ & $10.34 \pm 0.24^{* *}$ \\
\hline
\end{tabular}

a: 2 replicates; b: 3 replicates

*, **Significantly different from Mv9kr1 at the $\mathrm{P}<0.05$ level and at the $\mathrm{P}<0.01$ level, respectively

abbreviations: Glu - glutenin; Gli - gliadin; HMW - high molecular weight glutenins; LMW - low molecular weight glutenins; TOTAX - total arabinoxylan; UPP\% - unextractable polymeric protein; WEAX - water extractable arabinoxylan. 
Fig. 1

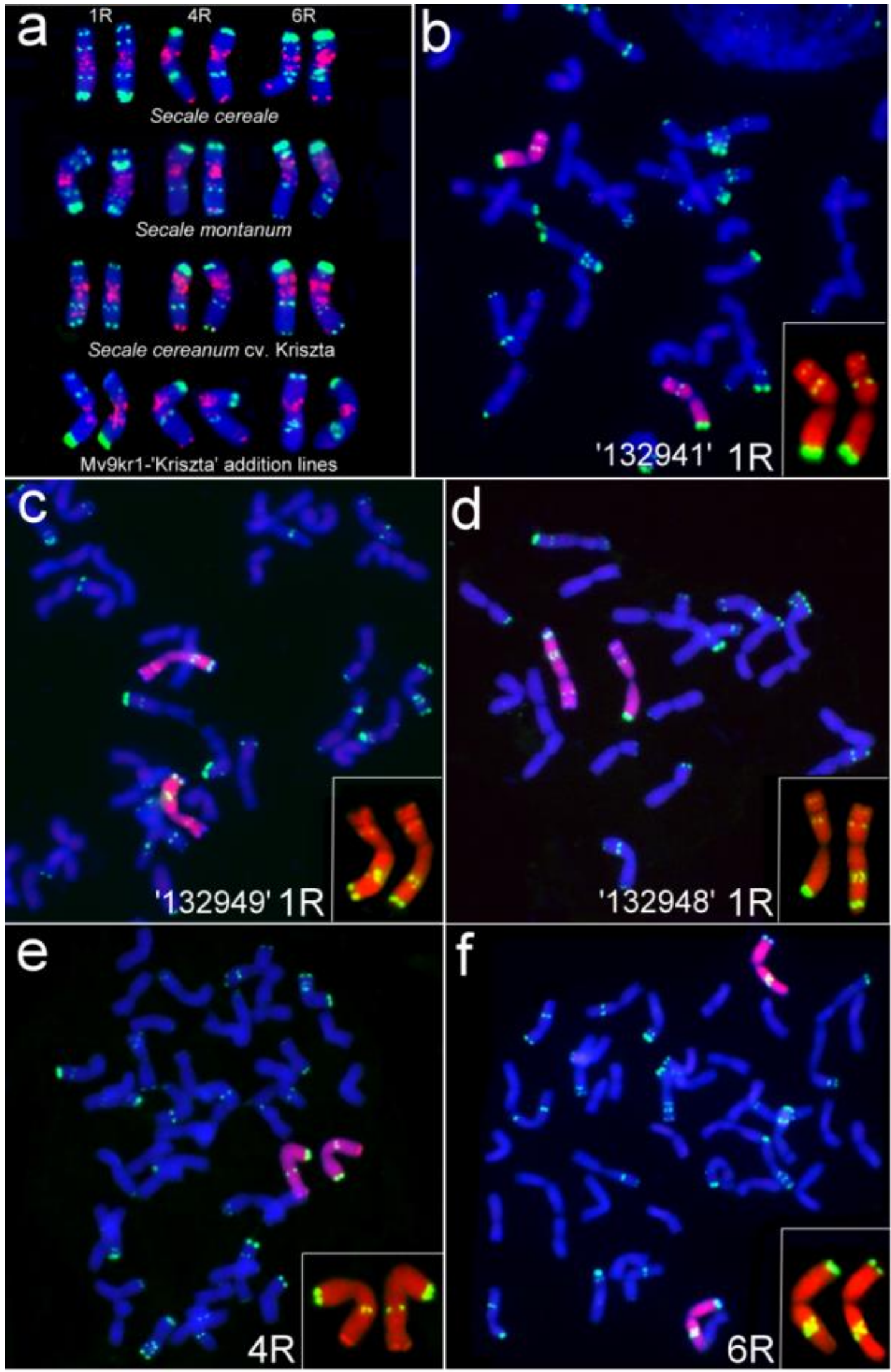


Fig. 2
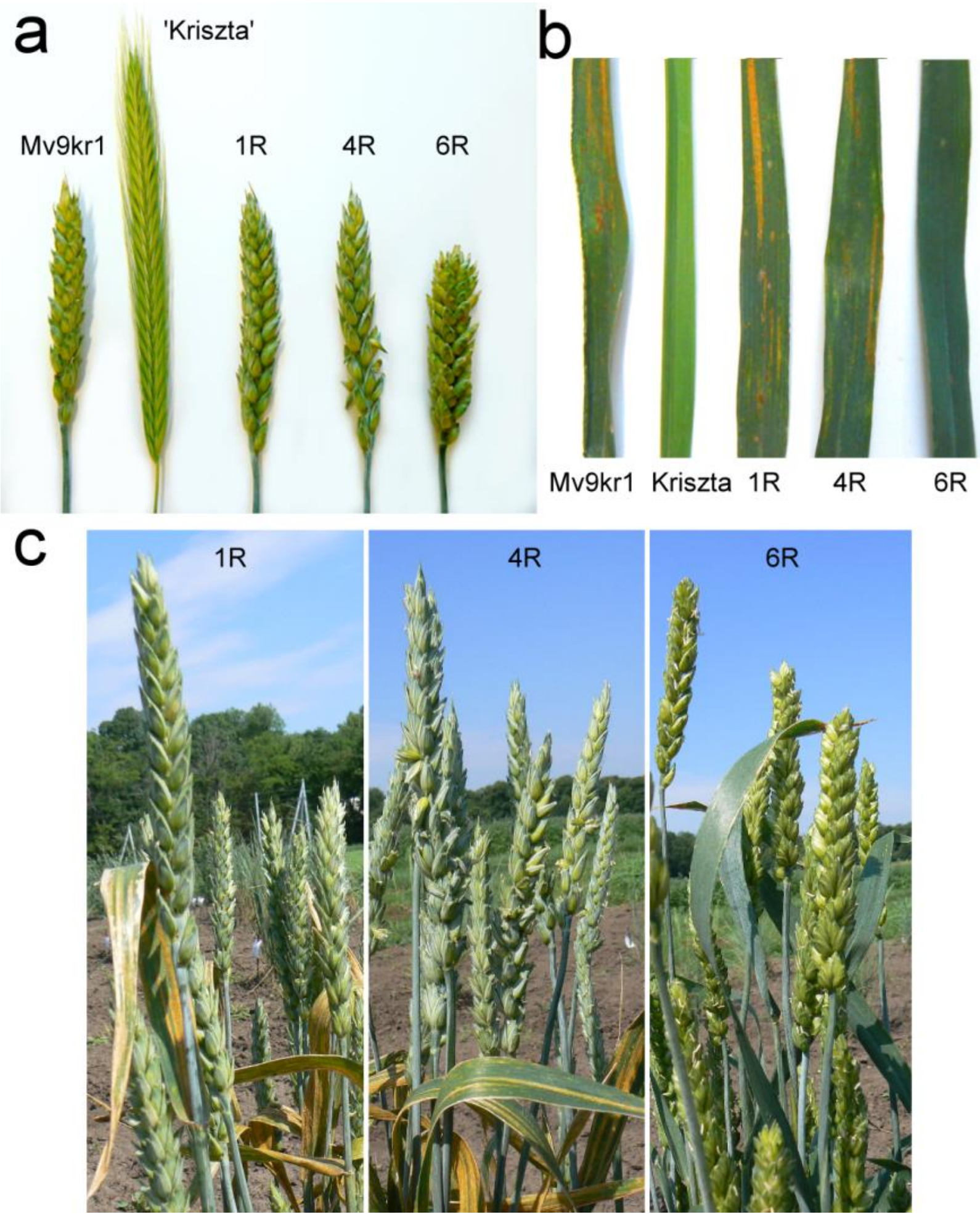
Fig. 3

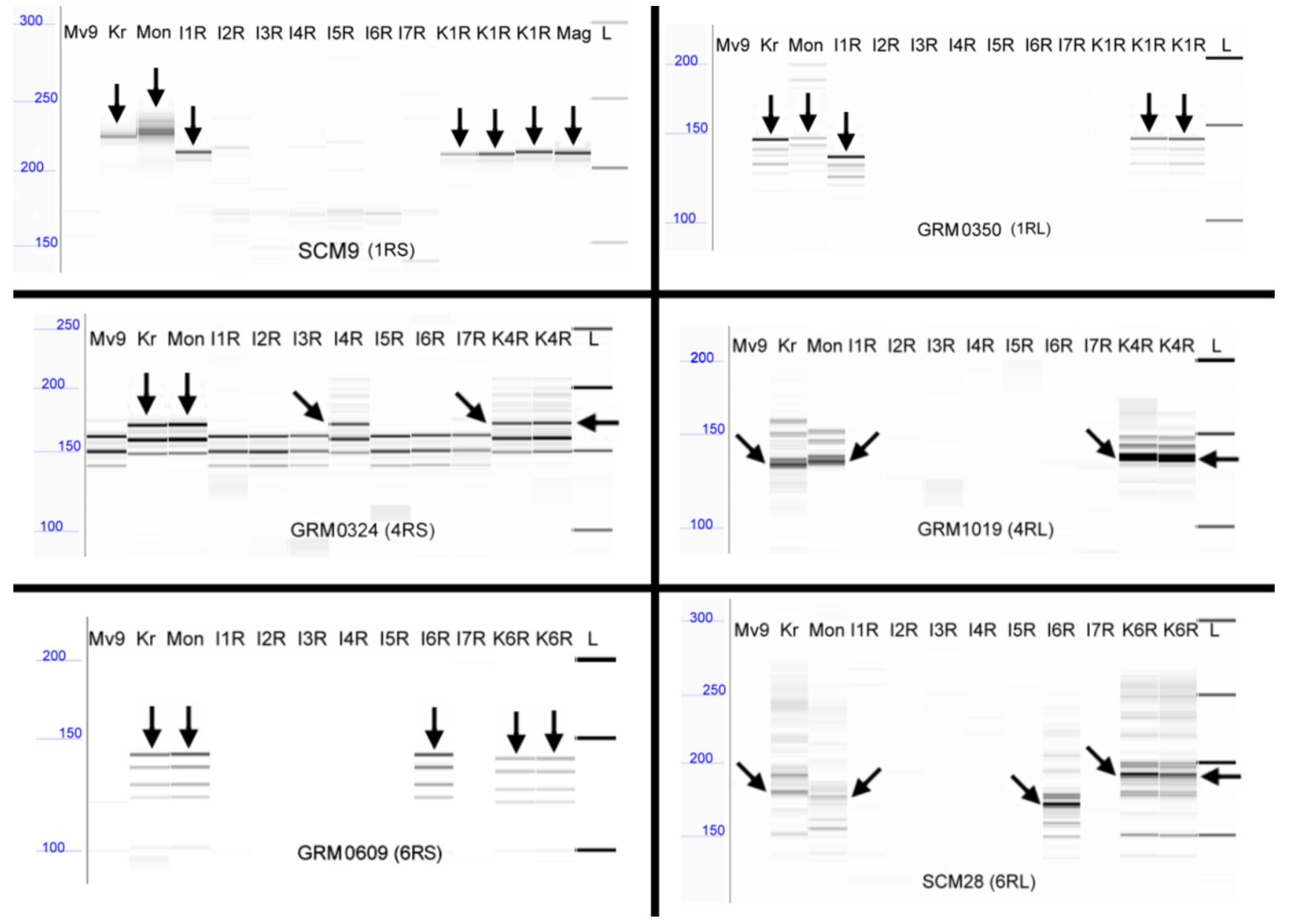

